Pacific Northwest

National Laboratory

Operated by Battelle for the

U.S. Department of Energy

\section{Fourth Annual Report: 2007 Pre- Construction Eelgrass Monitoring and Propagation for King County Outfall Mitigation}

\author{
DL Woodruff \\ NP Kohn \\ VI Cullinan \\ SL Southard \\ J Vavrinec
}

October 2007

Prepared for the U.S. Department of Energy

under Contract DE-AC05-76RL01830 


\section{DISCLAIMER}

This report was prepared as an account of work sponsored by an agency of the United States Government. Neither the United States Government nor any agency thereof, nor Battelle Memorial Institute, nor any of their employees, makes any warranty, express or implied, or assumes any legal liability or responsibility for the accuracy, completeness, or usefulness of any information, apparatus, product, or process disclosed, or represents that its use would not infringe privately owned rights. Reference herein to any specific commercial product, process, or service by trade name, trademark, manufacturer, or otherwise does not necessarily constitute or imply its endorsement, recommendation, or favoring by the United States Government or any agency thereof, or Battelle Memorial Institute. The views and opinions of authors expressed herein do not necessarily state or reflect those of the United States Government or any agency thereof.

\section{PACIFIC NORTHWEST NATIONAL LABORATORY \\ operated by \\ BATTELLE \\ for the}

UNITED STATES DEPARTMENT OF ENERGY

under Contract DE-AC05-76RL01830

Printed in the United States of America

Available to DOE and DOE contractors from the

Office of Scientific and Technical Information,

P.O. Box 62, Oak Ridge, TN 37831-0062;

ph: (865) 576-8401

fax: (865) 576-5728

email: reports@adonis.osti.gov

\footnotetext{
Available to the public from the National Technical Information Service,

U.S. Department of Commerce, 5285 Port Royal Rd., Springfield, VA 22161 ph: (800) 553-6847 fax: (703) 605-6900 email: orders@ntis.fedworld.gov

online ordering: http://www.ntis.gov/ordering.htm
}

This document was printed on recycled paper. 
PNNL-15678-4

\title{
Fourth Annual Report: \\ 2007 Pre-Construction Eelgrass \\ Monitoring and Propagation \\ for King County Outfall Mitigation
}

\author{
D. L. Woodruff \\ N. P. Kohn \\ V. I. Cullinan \\ S. L. Southard \\ J. Vavrinec \\ Marine Sciences Laboratory \\ Sequim, Washington
}

October 2007

Prepared for

King County Department of Natural Resources and Parks

Wastewater Treatment Division, Brightwater Project

under a Related Services Agreement

with the U.S. Department of Energy

Contract DE-AC05-76RL01830

Pacific Northwest National Laboratory

Richland, Washington 99352 


\section{Executive Summary}

King County proposes to build a new sewer outfall discharging to Puget Sound near Point Wells, Washington. At present, outfall construction is scheduled for 2008. The Point Wells site was selected to minimize effects on the nearshore marine environment, but unavoidable impacts to eelgrass (Zostera marina) beds are anticipated during construction. To mitigate these impacts and prepare for postconstruction restoration, King County began implementing a multiyear eelgrass monitoring and restoration program in 2004, with the primary goal of returning intertidal and shallow subtidal habitat and eelgrass to pre-construction conditions. Major program elements related to eelgrass are a) preconstruction monitoring, i.e., documenting initial eelgrass conditions and degree of fluctuation over 5 years prior to construction, b) eelgrass transplanting, including harvesting, offsite propagating, and stockpiling of local plants for post-construction planting, and c) post-construction planting and subsequent monitoring. The program is detailed in the Eelgrass Restoration and Biological Resources Implementation Workplan (King County 2006).

This report describes calendar year 2007 pre-construction activities conducted by Pacific Northwest National Laboratory (PNNL) for King County. Activities included continued propagation of eelgrass shoots at the PNNL Marine Sciences Laboratory (MSL) in Sequim, Washington, and monitoring of the experimental harvest plots in the marine outfall corridor area to evaluate recovery rates relative to harvest rates. In addition, 490 eelgrass shoots were also harvested from the Marine Outfall Corridor in July 2007 to supplement the plants in the propagation tank at the MSL, bringing the total number of shoots to 1464 . Eelgrass densities were monitored in four of five experimental harvest plots established in the Marine Outfall Corridor. Changes in eelgrass density were evaluated in year-to-year comparisons with initial harvest rates.

A net increase in eelgrass density from 2004 post-harvest to 2007 was observed in all plots, despite density decreases observed in 2006 in all plots and at most harvest rates. Eelgrass densities within individual subplots were highly variable from year to year, and the change in density in any interannual period was not related to initial 2004 harvest rate. Harvest rates of neighboring subplots did not appear to affect subplot eelgrass density (Woodruff et al. 2007). Three years post-harvest, eelgrass shoot densities were not significantly different from pre-harvest shoot densities at any harvest level.

Additional plans are being discussed with King County to harvest all eelgrass from the construction corridor and hold in the propagation tanks at the MSL for post-construction planting. Under this plan, plants that would have been lost to construction will be held offsite until construction is completed. This strategy reduces and possibly eliminates the need to harvest eelgrass from donor beds located south of the construction area, allowing them to remain undisturbed. However, if eelgrass is harvested from donor beds, the monitoring of eelgrass growth at different harvest rates should help determine an optimum harvest rate that supports rapid recovery of donor eelgrass beds. 


\section{Contents}

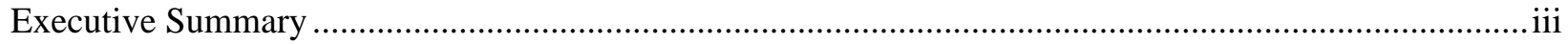

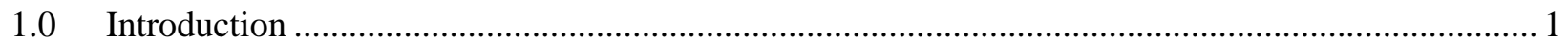

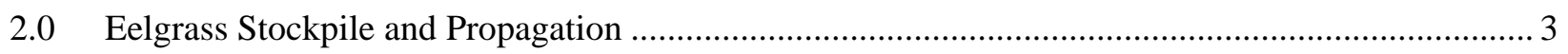

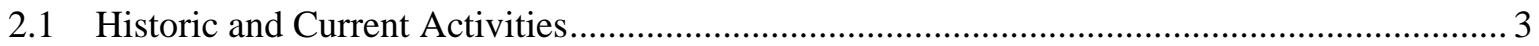

2.2 Eelgrass Stockpile and Propagation: Future Activity ........................................................ 4

3.0 Eelgrass Monitoring in Experimental Harvest Plots ................................................................. 5

3.1 Eelgrass Harvest Plot Design and Monitoring Methods ................................................... 5

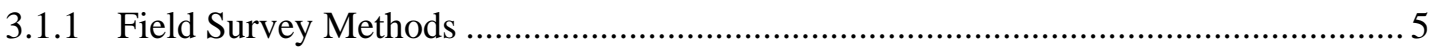

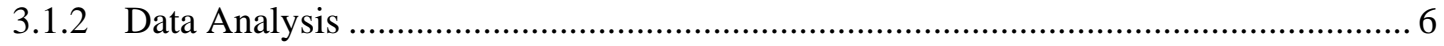

3.2 Experimental Harvest Plot Monitoring Results .............................................................. 7

3.3 Eelgrass Experimental Harvest Plots: Future Activity ..................................................... 14

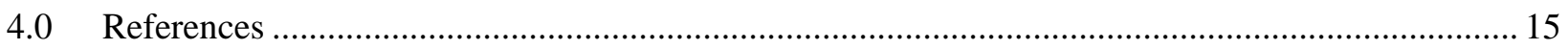

Appendix A Experimental Harvest Plot Data 


\section{Figures}

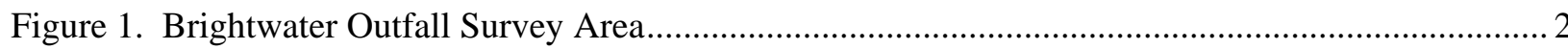

Figure 2. Site Map Indicating Experimental Harvest Plot Locations and the Percentage of Eelgrass

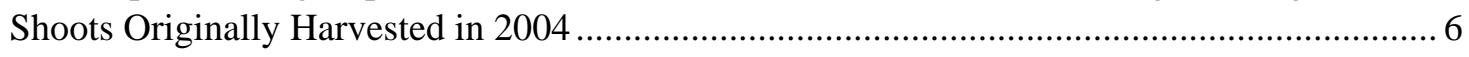

Figure 3. Representative Photographs of the Vegetation and Substrate Found in Plot 1, July 2007 ........... 7

Figure 4. Representative Photographs of the Vegetation and Substrate Found in Plot 2, July 2007 ........... 7

Figure 5. Representative Photographs of the Vegetation and Substrate Found in Plot 3, July 2007 ........... 8

Figure 6. Representative Photograph of the Vegetation and Substrate Found in Plot 5, July 2007 ............ 8

Figure 7. Legend Indicating Color Codes Used in Figures 8 through 12 to Indicate the Percentage of Eelgrass Harvested Per Subplot in 2004, and the Number of Shoots Counted within

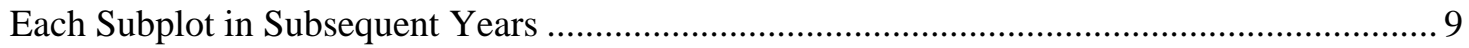

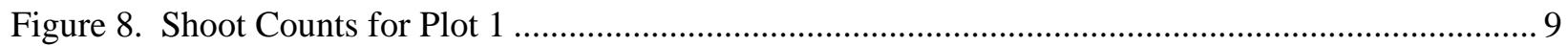

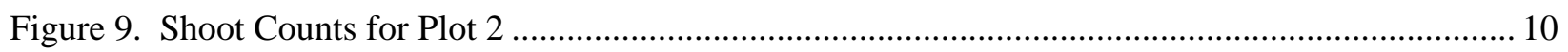

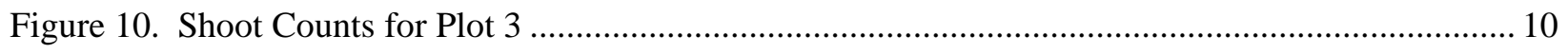

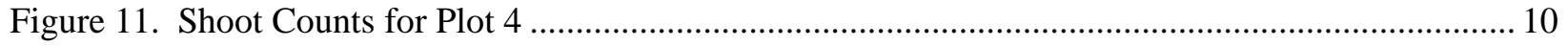

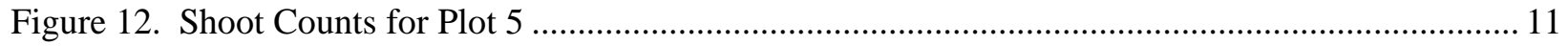

Figure 13. Mean Pre-harvest and Post-harvest Mean Eelgrass Densities by Plot..................................... 11

Figure 14. Mean Eelgrass Densities Before and After Harvest............................................................ 12

Figure 15. Interannual Proportion Change of Eelgrass Density as a Function of Harvest Rate................. 13

Figure 16. Proportional Average Rank of Shoot Density by Year ....................................................... 13

\section{Tables}

Table 1. Summary of Shoot Counts in Propagation Tanks, 2004-2007................................................. 4 
(this page intentionally left blank) 


\subsection{Introduction}

King County's Wastewater Treatment Division is planning to construct the Brightwater sewer outfall, which will discharge into Puget Sound near the King-Snohomish County line just south of Point Wells, Washington. The site was selected because of its narrow nearshore zone and the presence of fewer biological resources such as eelgrass that could be detrimentally affected by construction activities. Native eelgrass (Zostera marina) is present on the proposed outfall alignment, but is less abundant there than at other proposed sites. King County is implementing a mitigation program to monitor and restore those eelgrass beds that will be unavoidably disturbed by construction.

This report is the fourth in a series of annual reports on pre-construction activities conducted by the Pacific Northwest National Laboratory (PNNL) for the King County Brightwater Outfall eelgrass and biological resource mitigation program. Work related to this program is described in a Draft Eelgrass Restoration and Monitoring Plan (King County 2004), which was refined and further detailed in the Eelgrass Restoration and Biological Resources Implementation Workplan (King County 2006). PNNL tasks include the pre-construction mapping that was completed in 2004 (Woodruff et al. 2006a), subsequent monitoring of eelgrass beds in the outfall survey area, and eelgrass stockpiling and propagation for post-construction restoration during 2005, 2006 (Woodruff et al. 2006b, 2007), and 2007 (this report).

The Brightwater outfall survey area encompasses the Outfall (Eelgrass) Study Area, Marine Outfall Corridor, Eelgrass Reference Area, and the Eelgrass Reference Corridor (Figure 1). An Eelgrass Donor Site has been identified as a contingency in the event the harvest and propagation effort described below fails to provide sufficient eelgrass for transplanting. The Outfall Study Area extends 210 feet both north and south of the outfall pipeline alignment centerline, between $0 \mathrm{ft}$ mean lower low water (MLLW) and -25 ft MLLW, a zone in which eelgrass and associated macroalgae grow. Within the Outfall Study Area is the Marine Outfall Corridor, a narrow zone (20 ft wide) centered on the outfall pipeline alignment that includes $4 \mathrm{ft}$ on either side of the 12-ft-wide sheeted trench.

In accordance with the restoration and monitoring plan, PNNL harvested just over 300 eelgrass shoots from the Marine Outfall Corridor in 2004 to begin offsite propagation of plants for post-construction restoration (Woodruff et al. 2006a). This approach to restoration eliminates the need to remove plants from eelgrass meadows that would otherwise be undisturbed, while ensuring that the resident population is restored at the site. To help determine the optimum harvest range at which eelgrass will best recover, study plots were established within the Marine Outfall Corridor from which a designated percentage of eelgrass shoots were removed (i.e., 0\%, 5\%, 10\%, 25\%, 50\%, and 100\%). Documentation of 2005 and 2006 eelgrass propagation and monitoring activities, along with eelgrass recovery rates were reported in Woodruff et al. (2006b, 2007). Eelgrass propagation activities and progress during 2007 are detailed in Section 2 of this report. Documentation of monitoring activities and eelgrass recovery rates are provided in Section 3. 


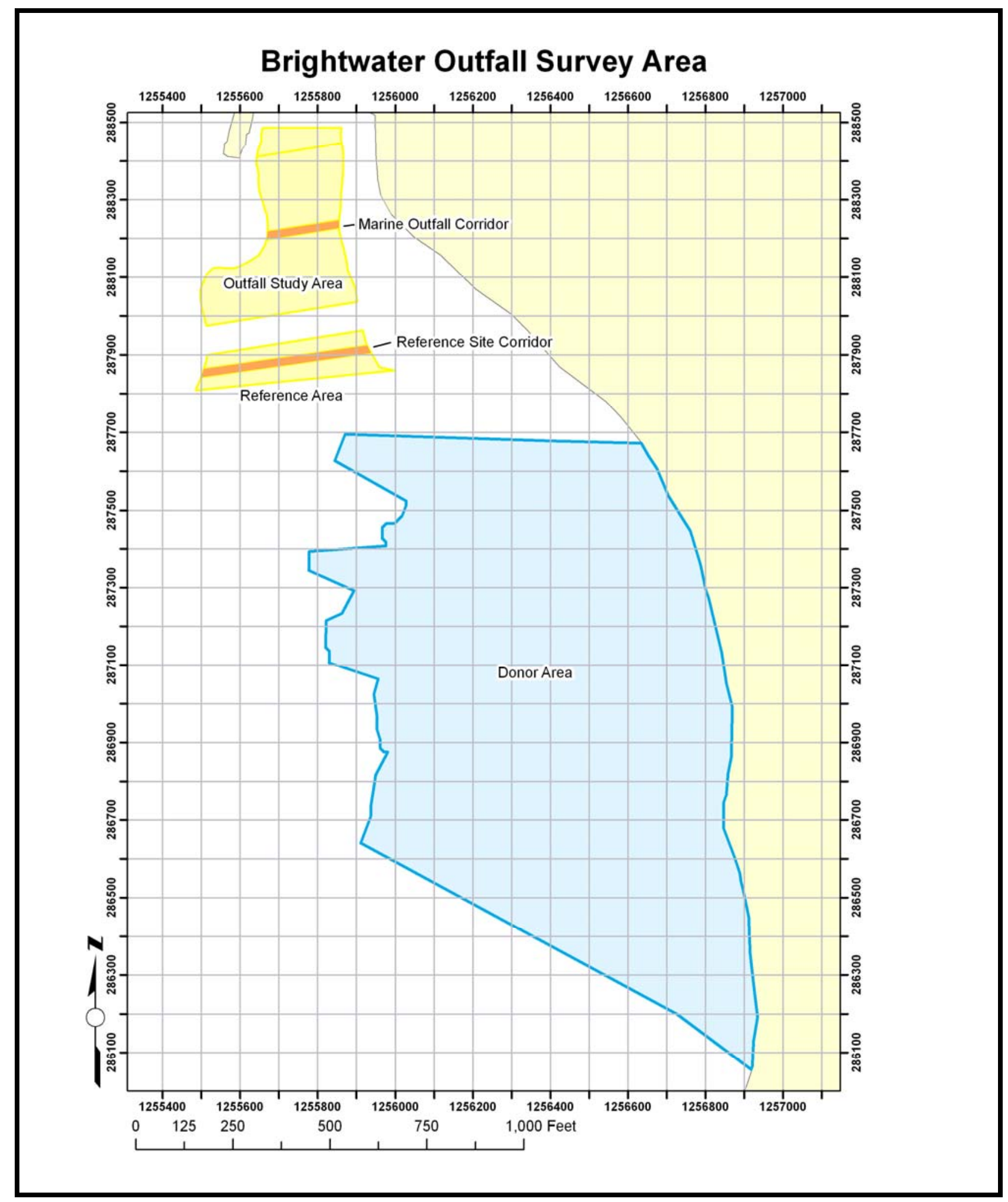

Figure 1. Brightwater Outfall Survey Area 


\subsection{Eelgrass Stockpile and Propagation}

As part of the eelgrass stockpile and propagation task, PNNL divers selectively and systematically harvested eelgrass shoots from the Marine Outfall Corridor using a "bare-root method" (Woodruff et al. 2006a). The harvested shoots were transported to the PNNL Marine Sciences Laboratory (MSL) in Sequim, Washington, where they were planted in outdoor tanks containing medium-grained sand and supplied with continuously flowing ambient, unfiltered seawater. Several techniques are used to increase the eelgrass population in the tanks to supply the maximum number of plants for post-construction restoration planting, such as collection of flowering shoots to enhance natural deposition of seeds onto the bottom. Vegetative reproduction also occurs through natural growth of the rhizome and root system. Propagation of plants from the site eliminates the need to disturb a natural eelgrass bed for the purpose of transplanting to another location; it also ensures that the same genetic population is restored to the site.

\subsection{Historic and Current Activities}

Divers harvested 305 eelgrass shoots from the Marine Outfall Corridor in 2004 and another 1,500 shoots were harvested in 2006 (Woodruff et al. 2006a, 2007).

Stockpile and propagation activities that occurred in 2007 involved collection of an additional 490 shoots from the Marine Outfall Corridor by divers, and also maintenance and monitoring of eelgrass in the MSL propagation tanks. The stockpiled eelgrass population was not supplemented with flowering shoots this year from the proposed Marine Outfall Corridor, because very few flowering shoots were noted at the site during our July survey.

The total number of shoots currently held in the propagation tanks at the MSL is 1464, including the recently collected 490 shoots, which is a decrease from the 4732 shoots counted in the tanks last summer. The number of shoots in the tanks had risen dramatically between 2005 and 2006. Because the plants appeared vigorous and healthy, we moved all plants during late summer 2006 from a smaller 6.1-m diameter tank to a larger 9.1-m diameter tank to better accommodate expected growth and reproduction. Unfortunately, after this transplant process, many of the shoots did not survive the year. We expect, however, to see the shoot counts increase by next summer and beyond. Similar to 2004 and 2006, the shoots harvested in 2007 were collected from areas outside the monitoring plots established in 2004 so as not to affect assessments of eelgrass recovery rates (Section 3).

A summary of the shoot counts in the propagation tanks since the start of this project is provided in Table 1. The comments in the table are directly related to the increase and decrease in shoot counts that are reported. While the loss of the shoots between 2006 and 2007 is unfortunate, we fully expect that the numbers will increase during the next year, and until the plants are transplanted back to the marine outfall corridor. 
Table 1. Summary of Shoot Counts in Propagation Tanks, 2004-2007

\begin{tabular}{|l|c|r|l|}
\hline $\begin{array}{c}\text { Assessment } \\
\text { Date }\end{array}$ & $\begin{array}{c}\text { Number of Shoots } \\
\text { Harvested and } \\
\text { Planted }\end{array}$ & $\begin{array}{c}\text { Number of Shoots } \\
\text { (change from } \\
\text { previous count) }\end{array}$ & \multicolumn{1}{|c|}{$\begin{array}{c}\text { Comments } \\
\text { (reason for increase or decrease) }\end{array}$} \\
\hline Oct 2004 & 305 & $195 \quad(-210)$ & Initial harvest and transplant \\
\hline Nov 2004 & & $397 \quad(+202)$ & Natural propagation \\
\hline Sept 2005 & & $3232 \quad(+835)$ & Natural propagation \\
\hline Aug 2006 & 1500 & $4732 \quad(+1500)$ & Additional harvest and planting \\
\hline Aug 2006 & & $974 \quad(-3748)$ & Transplant shock and loss \\
\hline July 2007 & 490 & $1464 \quad(+490)$ & Additional harvest and planting \\
\hline July 2007 & & & \\
\hline
\end{tabular}

\subsection{Eelgrass Stockpile and Propagation: Future Activity}

Maintenance and monitoring of the propagation tank, including the annual count of eelgrass shoots, will continue in 2008. In addition, all shoots from the Marine Outfall Corridor may be harvested immediately prior to construction trenching in 2008 or 2009 and brought to the MSL for holding and propagation until transplanted back to the Marine Outfall Corridor and Outfall Study Area. 


\subsection{Eelgrass Monitoring in Experimental Harvest Plots}

A common uncertainty with many eelgrass restoration projects is the effect of removal of eelgrass from donor meadows. Harvest levels have typically been restricted to $10 \%$ or less of the total abundance to minimize effects; however, there are no published studies or quantitative data to support anecdotal observations that harvest has a small, short-term effect on eelgrass density. The Eelgrass Restoration and Biological Resources Implementation Workplan (King County 2006) detailed a pre- and post-harvest experimental monitoring plan to provide quantitative data on eelgrass recovery rates after shoot harvest.

As part of the experimental design, eelgrass shoot density was determined in semi-permanent experimental plots established in the Marine Outfall Corridor prior to the 2004 eelgrass harvest (Woodruff et al. 2006a). Eelgrass density in these plots was monitored to assess post-harvest recovery rates in 2005 (Woodruff et al. 2006b) and 2006 (Woodruff et al. 2007). The experimental plots were monitored again in mid-July 2007, most likely for the last time prior to construction. Monitoring and data analysis methods are provided below in Section 3.1; 2007 monitoring results are presented and compared with prior years' data in Section 3.2. As in 2006, 2007 eelgrass monitoring focused on the experimental harvest plots established in 2004 for changes in eelgrass shoot density (recovery), now 3 years after initial harvest.

\subsection{Eelgrass Harvest Plot Design and Monitoring Methods}

In 2004, eelgrass was harvested at different percentages from experimental plots, described in Woodruff et al. 2006a and summarized here. Five plots were established as semi-permanent $2-\mathrm{m}^{2}(1-\mathrm{x} 2-\mathrm{m})$ rectangular plots, located in eelgrass patches inside the Marine Outfall Corridor. Each 2- $\mathrm{m}^{2}$ plot was divided into eight $0.25-\mathrm{m}^{2}$ treatment subplots or cells. Each rectangular plot had 2 subplots of $100 \%$ harvest located on one end of the rectangle (to minimize potential effects of $100 \%$ harvest on adjacent cells), and two subplots of $0 \%$ harvest placed randomly within the six remaining cells. The four remaining subplots were randomly assigned to be $5 \%, 10 \%, 25 \%$, or $50 \%$ harvest. The plot locations and experimental harvest percentages for each subplot are shown in Figure 2.

\subsubsection{Field Survey Methods}

The 2007 eelgrass monitoring of the experimental harvest plots was conducted by PNNL's scientific dive team on July 19, 2007. Divers located markers associated with four of the five previously established plots and counted eelgrass shoots in each of these plots and subplots. Plot 4 markers could not be located. This plot is located at the shallow end of the construction corridor in the intertidal zone, at a depth of approximately $-1 \mathrm{ft}$ MLLW (Figure 2). The survey stakes marking the shoreward end of the Marine Outfall Corridor could not be located either; hence plot 4 could not be relocated accurately for the 2007 survey. The divers qualitatively observed cobble substrate and sparse eelgrass in the vicinity of Plot 4 . Shoot counts were recorded in all subplots of plots 1, 2, 3, and 5, and underwater photographs taken at each of these plots. Drift or unattached eelgrass and algae wrack, which had been noted at the deep end of the corridor in 2005 and 2006, was not observed in 2007. 


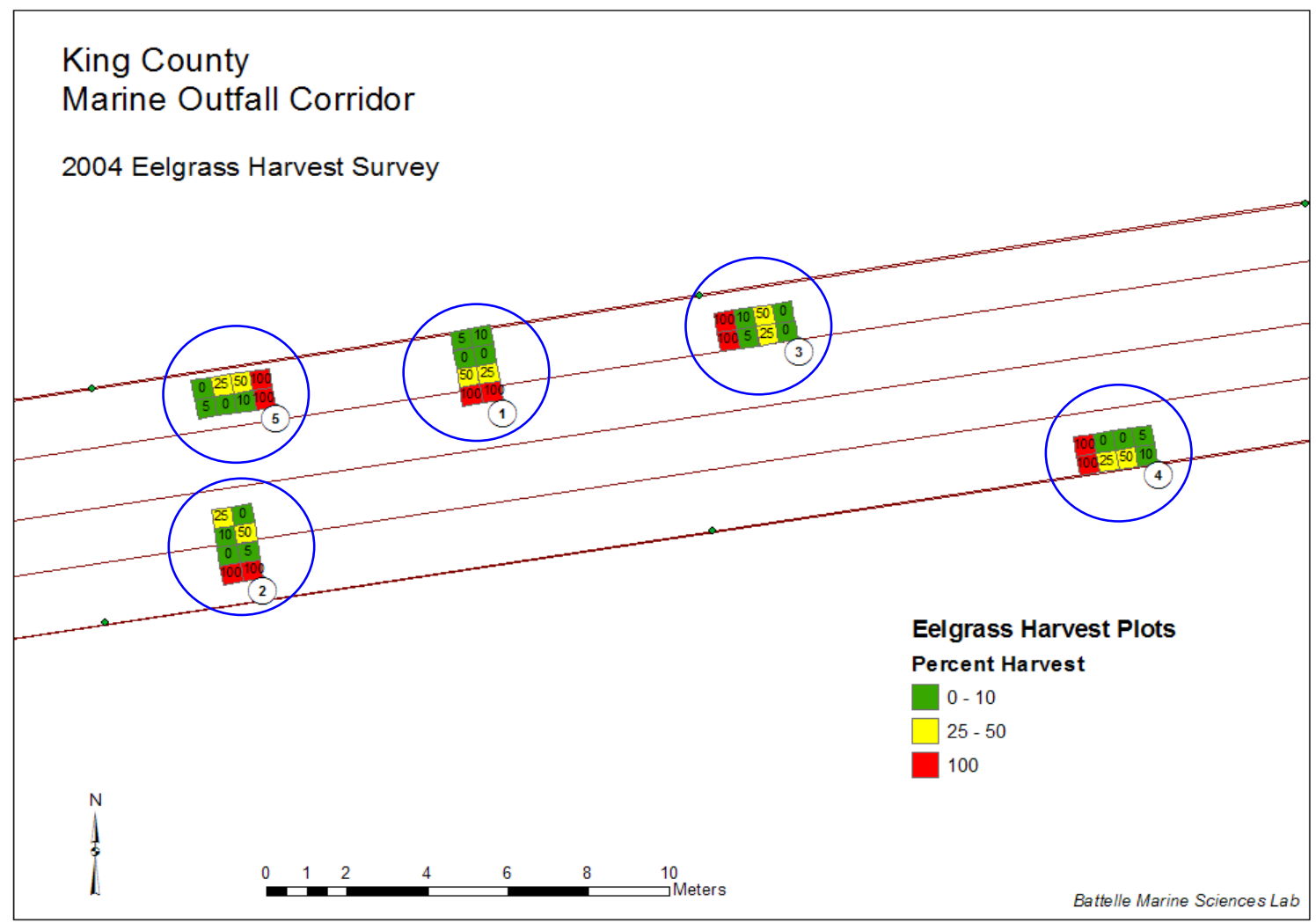

Figure 2. Site Map Indicating Experimental Harvest Plot Locations and the Percentage of Eelgrass Shoots Originally Harvested in 2004

\subsubsection{Data Analysis}

Annual monitoring data for eelgrass density in the 2- $\mathrm{m}^{2}$ experimental harvest plots (each containing eight $0.25-\mathrm{m}^{2}$ subplots) were compared with the 2004 data for post-harvest eelgrass density. The interannual differences between plots overall and within individual subplots were calculated. Statistical analyses were conducted to assess the effect of initial harvest rate on eelgrass abundance (expressed as proportion of change in density). These analyses were conducted for the periods 2004 to 2005, 2005 to 2006, 2006 to 2007, and net change from 2004 to 2007. Because a number of experimental plot markers were missing in 2005 and needed to be resurveyed, there is more uncertainty associated with the 2004 to 2005 and net eelgrass density changes from 2004 than with the 2005 to 2006 and 2006 to 2007 density changes. However, this uncertainty was addressed in 2006 and was found not to influence the overall conclusions (Woodruff et al. 2007). Also in 2006, data were statistically analyzed to assess whether eelgrass density in an individual subplot was affected by the harvest rate in adjacent subplots ("neighbor effect") (Woodruff et al. 2007). Density within a subplot did not appear to be affected by the harvest rate of adjacent subplots; therefore, the "neighbor effect” was not analyzed in 2007. 


\subsection{Experimental Harvest Plot Monitoring Results}

Figure 3 through Figure 6 are representative photographs of the vegetative cover and bottom substrate of each plot surveyed in 2007. Plots 1, 2, and 5 lie in the -5 to $-10 \mathrm{ft}$ MLLW depth range; Plot 3 is in the -1 to $-5 \mathrm{ft}$ MLLW depth range. Where present in a photograph, the white PVC frame covers $0.25 \mathrm{~m}^{2}$. All surveyed plots had sandy substrate. Substrate in the vicinity of Plot 4 (not surveyed in 2007), was reported to have coarser substrate (cobble, shell) than that of the deeper plots, which is consistent with previous surveys (Woodruff et al. 2006a, 2006b, 2007).
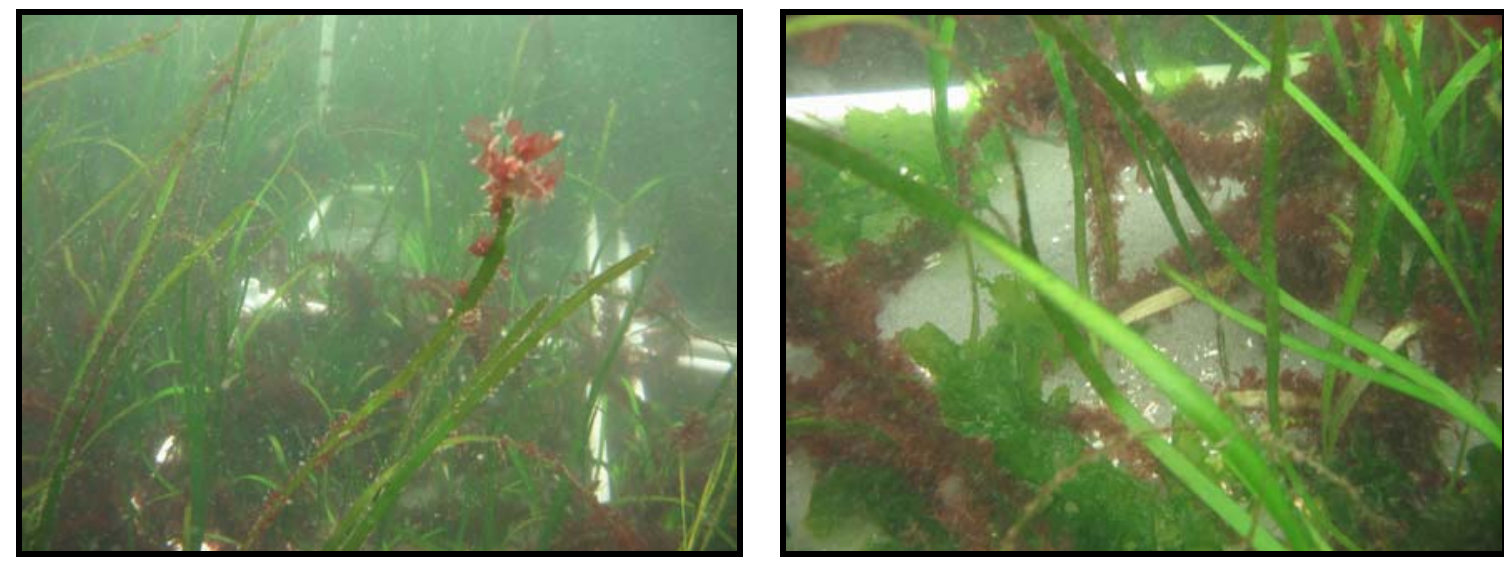

Figure 3. Representative Photographs of the Vegetation and Substrate Found in Plot 1, July 2007
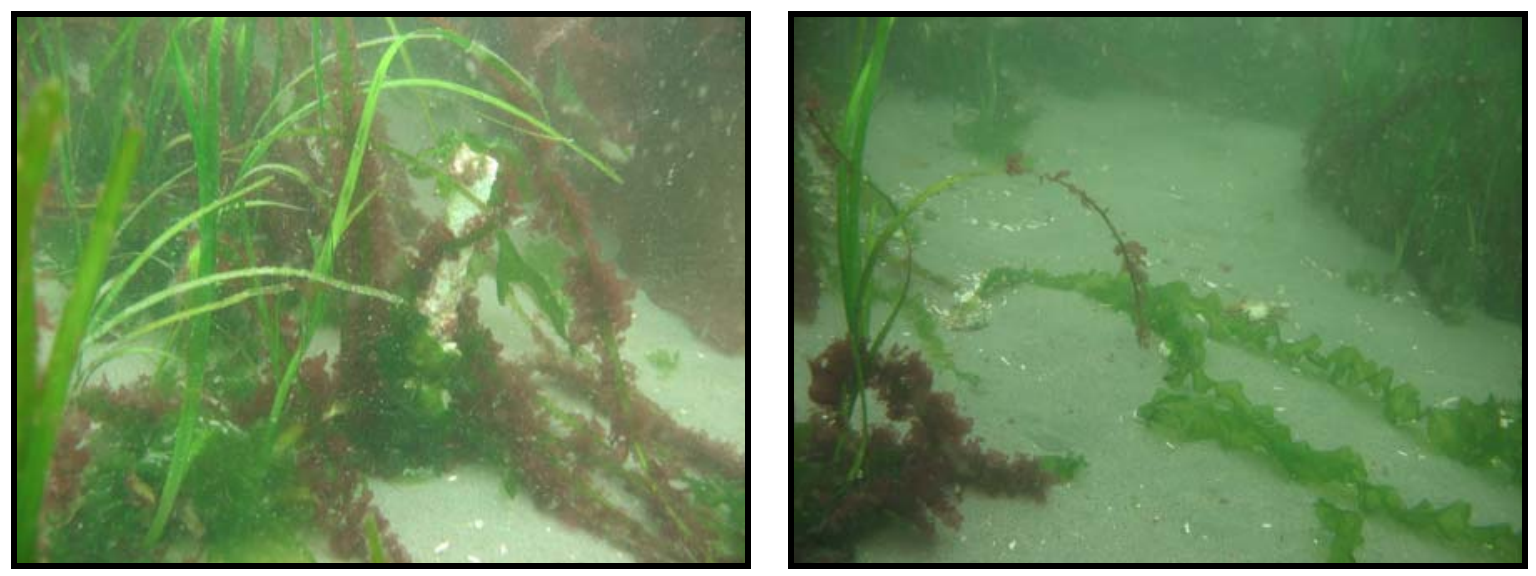

Figure 4. Representative Photographs of the Vegetation and Substrate Found in Plot 2, July 2007 

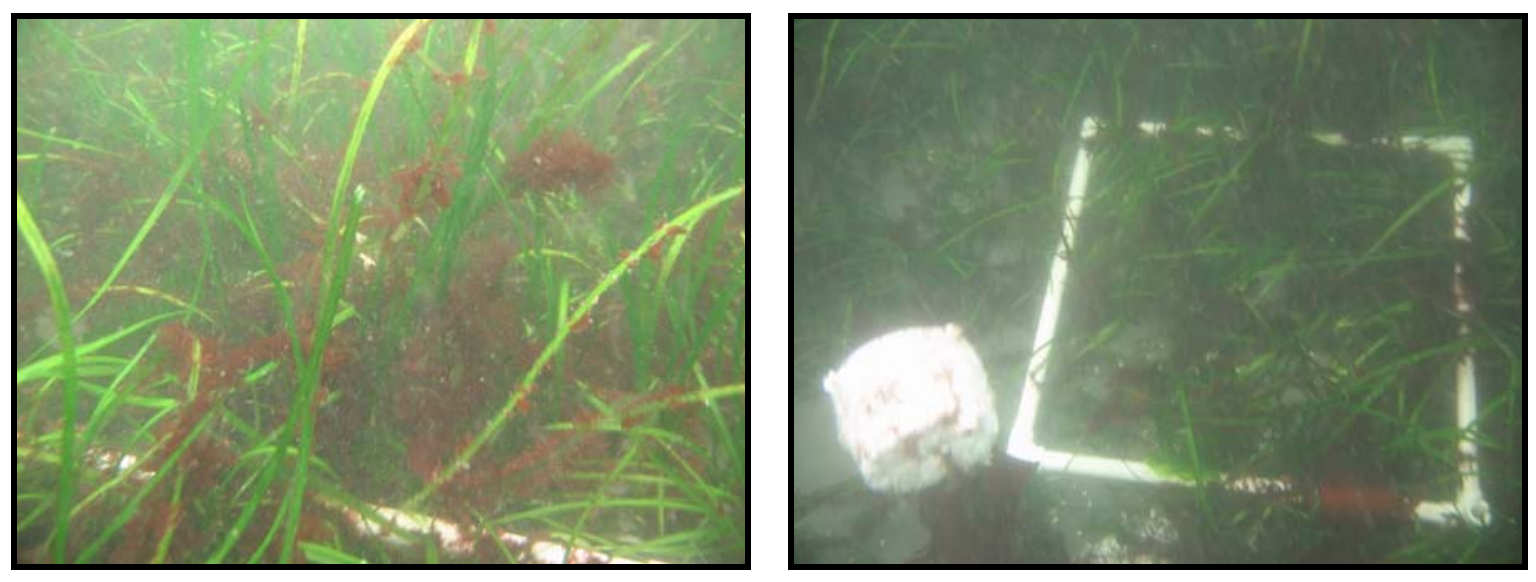

Figure 5. Representative Photographs of the Vegetation and Substrate Found in Plot 3, July 2007

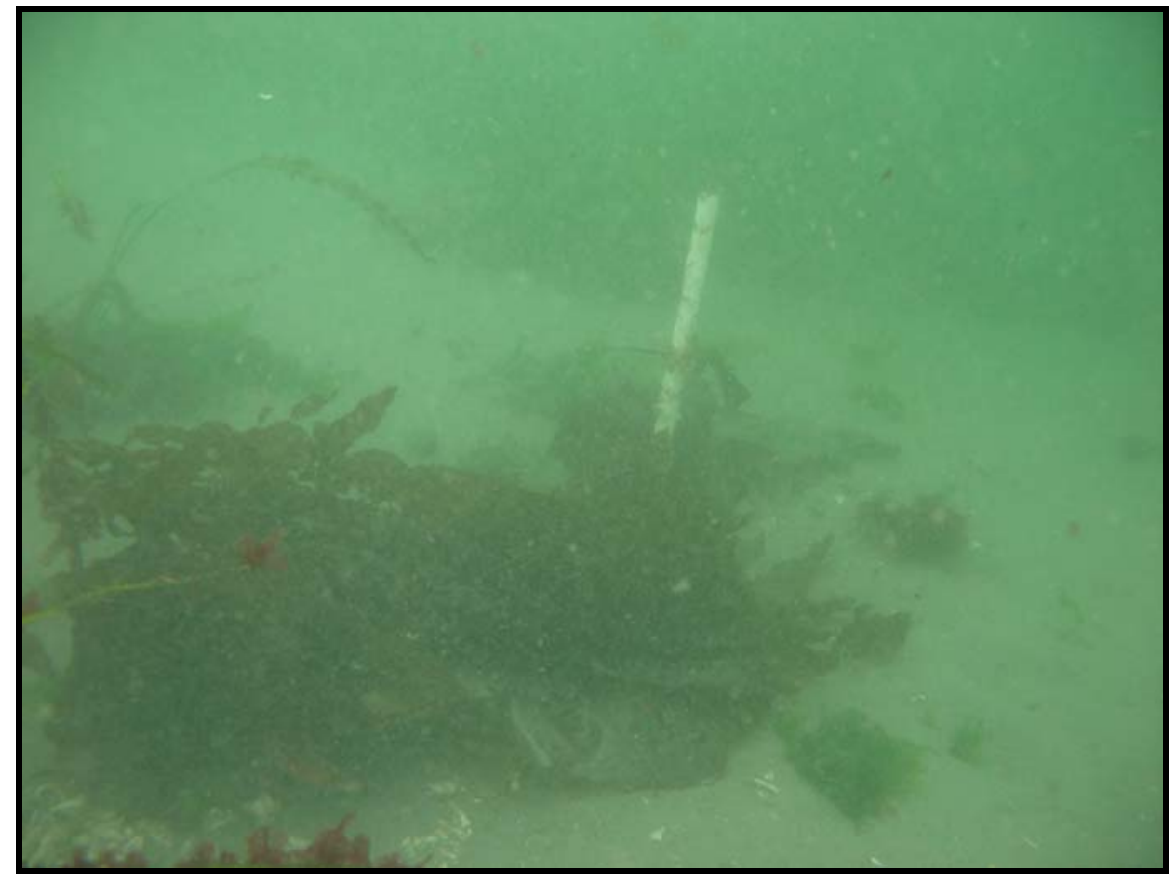

Figure 6. Representative Photograph of the Vegetation and Substrate Found in Plot 5, July 2007 
Monitoring results since 2004 in the five experimental harvest plots located in the Marine Outfall Corridor are tabulated in Appendix A (Table A-1). Figure 7 represents the color coding used in Figures 8 through 12. For descriptive purposes, the maximum number of eelgrass shoots previously counted in a single subplot (67 in 2005) was divided into thirds to establish a gradient scale indicating low (0 to 22 shoots per $0.25 \mathrm{~m}^{2}$ ), moderate ( 12 to 44 shoots per $0.25 \mathrm{~m}^{2}$ ), and high ( 45 or more shoots per $0.25 \mathrm{~m}^{2}$ ) shoot densities for the Marine Outfall Corridor experimental harvest plots (Figure 7). Harvest rates, pre-harvest data, and annual plot and subplot data are presented graphically in Figure 8 through Figure 12.

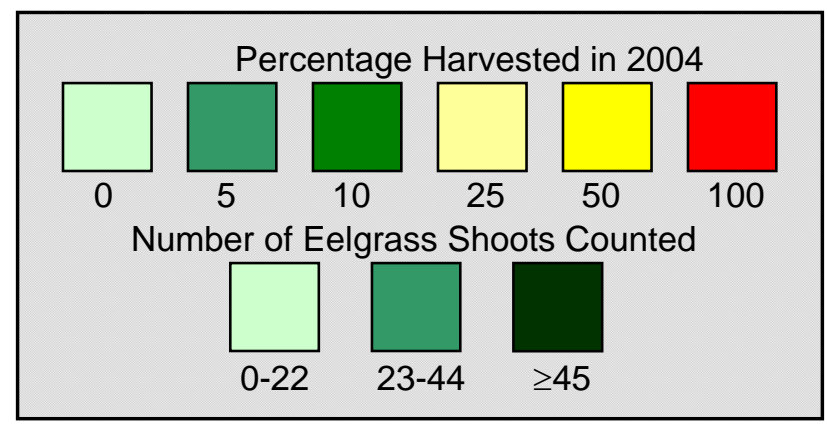

Figure 7. Legend Indicating Color Codes Used in Figures 8 through 12 to Indicate the Percentage of Eelgrass Harvested Per Subplot in 2004 and the Number of Shoots Counted within Each Subplot in Subsequent Years

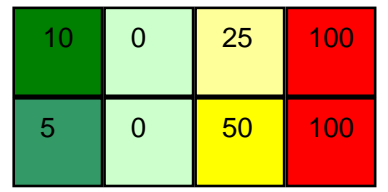

PLOT 1 Percentage Harvested 2004

\begin{tabular}{|l|l|l|l|}
\hline 41 & 23 & 6 & 24 \\
\hline 33 & 10 & 8 & 40 \\
\hline
\end{tabular}

2005

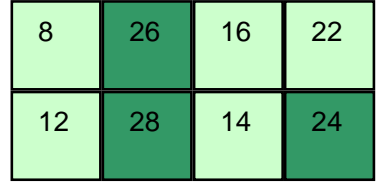

Pre-Harvest 2004

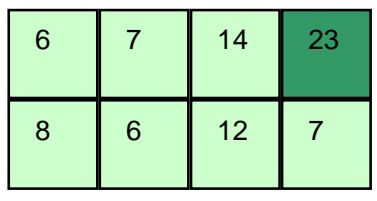

2006

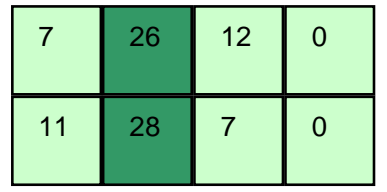

Post-Harvest 2004

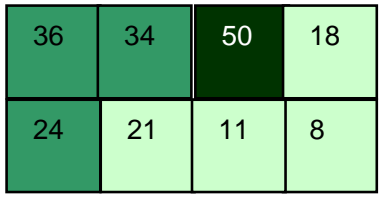

2007

Shoot Counts

Figure 8. Shoot Counts for Plot 1 


\begin{tabular}{|c|c||c|c|}
\hline 0 & 50 & $\underline{5}$ & 100 \\
\hline 25 & 10 & 0 & 100 \\
\hline
\end{tabular}

PLOT 2 Percentage Harvested 2004

\begin{tabular}{|l|l|l|l|}
\hline 19 & 15 & 12 & 1 \\
\hline 11 & 11 & 1 & 3 \\
\hline
\end{tabular}

2005

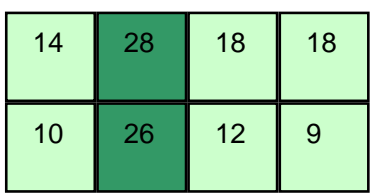

Pre-Harvest 2004

\begin{tabular}{|l|l|l||l|}
\hline 8 & 15 & 0 & 8 \\
\hline 8 & 15 & 8 & 0 \\
\hline
\end{tabular}

2006

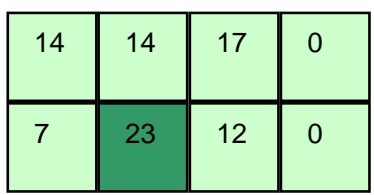

Post-Harvest 2004

\begin{tabular}{|l|l||l|l|}
\hline 0 & 24 & 2 & 2 \\
\hline 12 & 26 & 1 & 6 \\
\hline
\end{tabular}

2007

Shoot Counts

Figure 9. Shoot Counts for Plot 2

\begin{tabular}{|c|c|c|c|}
\hline 100 & 10 & 50 & 0 \\
\hline 100 & 5 & 25 & 0 \\
\hline
\end{tabular}

PLOT 3 Percentage Harvested 2004

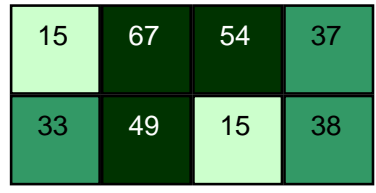

2005

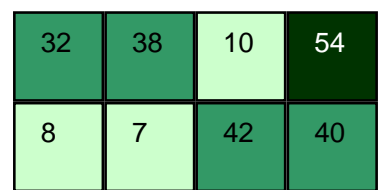

Pre-Harvest 2004

\begin{tabular}{|l|l|l|l|}
\hline 28 & 17 & 2 & 21 \\
\hline 27 & 11 & 26 & 31 \\
\hline
\end{tabular}

2006

Shoot Counts

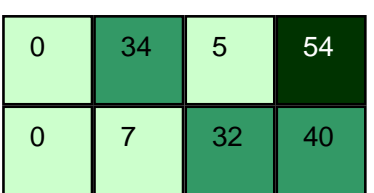

Post-Harvest 2004

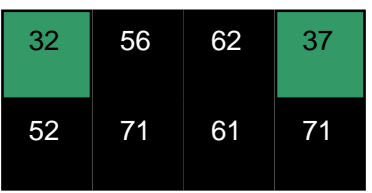

2007

Figure 10. Shoot Counts for Plot 3

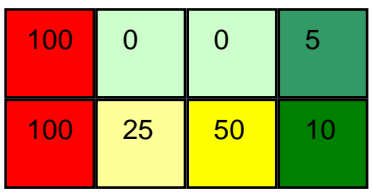

PLOT 4 Percentage Harvested 2004

\begin{tabular}{|c|c|c|c|}
\hline 4 & 32 & 61 & 32 \\
\hline 17 & 25 & 7 & 23 \\
\hline
\end{tabular}

2005

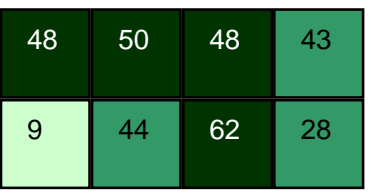

Pre-Harvest 2004

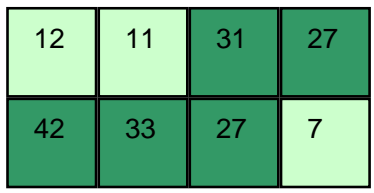

2006

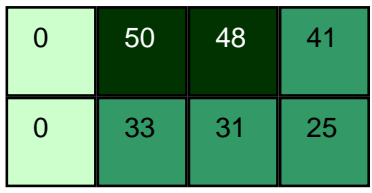

Post-Harvest 2004

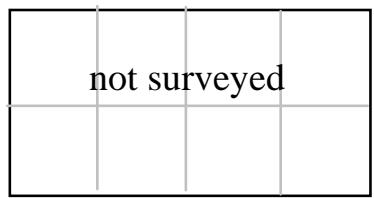

2007

Shoot Counts

Figure 11. Shoot Counts for Plot 4 


\begin{tabular}{|c|c|c|c|}
\hline 0 & 25 & 50 & 100 \\
\hline 5 & 0 & 10 & 100 \\
\hline
\end{tabular}

PLOT 5 Percentage Harvested 2004

\begin{tabular}{|l|l|l|l|}
\hline 1 & 19 & 12 & 0 \\
\hline 1 & 13 & 0 & 0 \\
\hline
\end{tabular}

2005

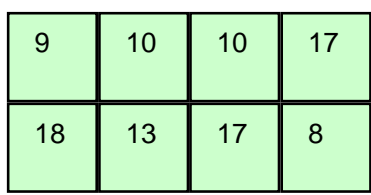

Pre-Harvest 2004

\begin{tabular}{|l|l|l|l|}
\hline 3 & 2 & 1 & 0 \\
\hline 6 & 6 & 1 & 0 \\
\hline
\end{tabular}

2006

\begin{tabular}{|c|c|c|c|}
\hline 9 & 8 & 5 & 0 \\
\hline 17 & 13 & 15 & 0 \\
\hline
\end{tabular}

Post-Harvest 2004

\begin{tabular}{|c|c|c|c|}
\hline 2 & 0 & 0 & 0 \\
\hline 13 & 0 & 0 & 0 \\
\hline
\end{tabular}

2007

Shoot Counts

Figure 12. Shoot Counts for Plot 5

Mean eelgrass density in each experimental harvest plot varied over time (Figure 13). Results were mixed, with some plot densities increasing between 2004 post-harvest and 2007 (Plots 1 and 3) and the remaining decreasing slightly (Plots 2, 4, and 5). In 2007, shoot densities were similar to or higher than those in 2006 in all surveyed plots; eelgrass densities in Plots 1 and 3 were higher in 2007 than those in any other survey, including those in the 2004 pre-harvest.

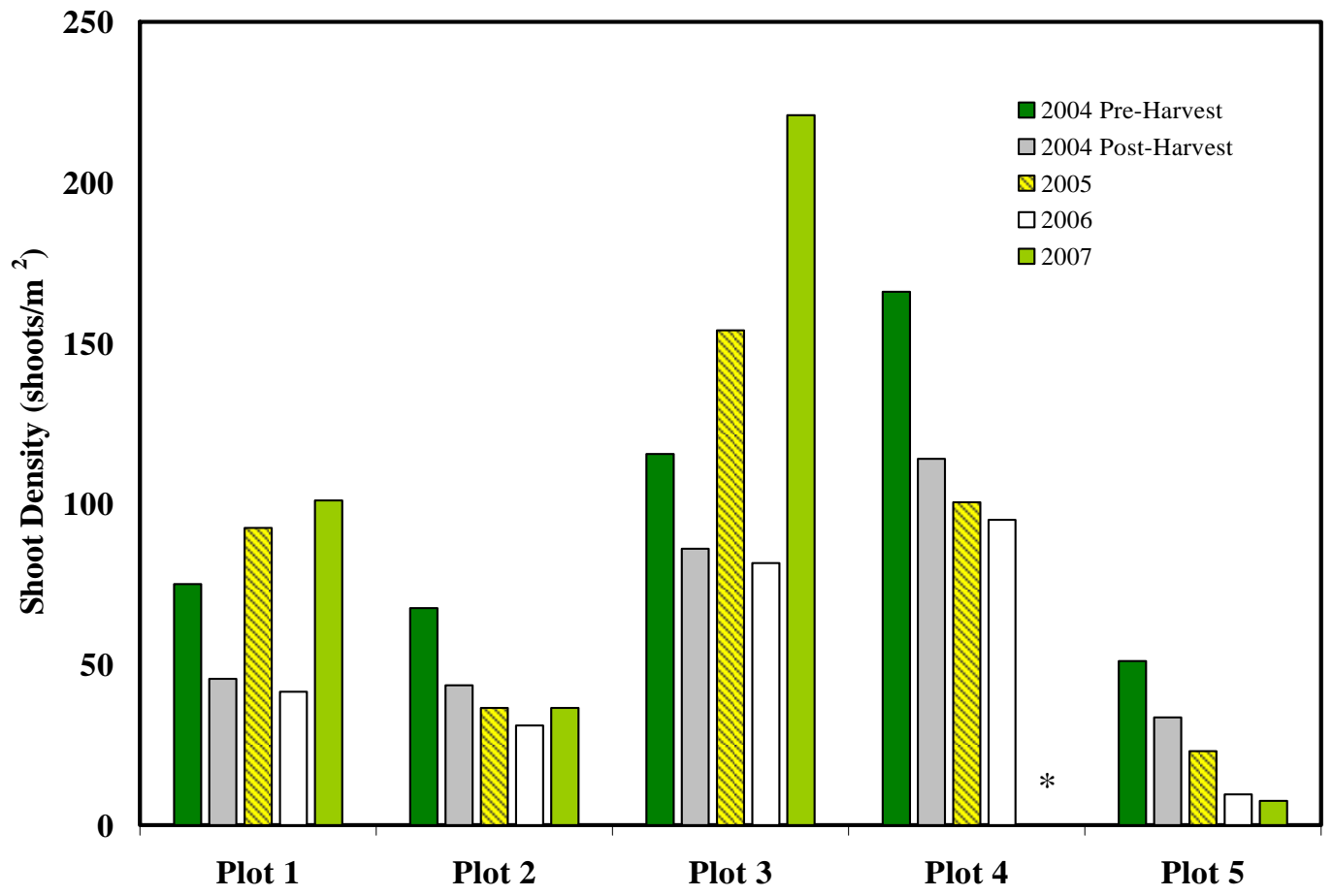

Figure 13. Mean Pre-harvest and Post-harvest Mean Eelgrass Densities by Plot (* Plot 4 not surveyed in 2007) 
The primary focus of this study was to examine changes in eelgrass density relative to the rate of harvest. As noted earlier, harvest rates from eelgrass donor sites are typically kept to $10 \%$ or less to minimize effects on the donor meadow. The experimental harvest plot and subplot data were further analyzed to examine the interannual changes between subplots harvested at six different percentage levels: $0 \%$ (control), 5\%, 10\%, 25\%, 50\%, and 100\% harvest. Mean pre- and post-harvest eelgrass densities by target harvest rate are provided in Figure 14 (data are tabulated in Appendix A, Table A-2). Although shoot densities had either declined or changed only slightly from 2005 to 2006, increases in shoot densities were observed from 2006 to 2007 at all harvest rates except 100\% (no change in shoot density). The 2007 shoot densities were similar to 2005 densities at most harvest rates, with a notable increase in density observed at the $25 \%$ harvest rate. Since the 2004 harvest, a net decrease in density was observed where no eelgrass had been harvested, whereas net increases in density occurred at the intermediate harvest rates (Figure 14). In subplots where $100 \%$ of eelgrass was harvested, eelgrass reestablished in the following year (2005) but density did not change significantly in subsequent years (2006, 2007) (Figure 14).

The results presented in Figure 14 indicate that post-harvest eelgrass densities at every harvest rate were highly variable. Figure 15 shows that growth, expressed as the proportion of change in eelgrass density, in each monitoring interval was also variable. Proportion of change in eelgrass density was not significantly correlated with harvest rates in the 2005 to 2006 period $(r=0.25)$ or in the 2006 to 2007 period $(r=-0.03)$. This observation is further illustrated in Figure 16, in which ranks of eelgrass density are related to harvest level until 2007, showing that harvest rate no longer influences density after 2006 or two years post-harvest. The average rank of each harvest class by year (Kruskal-Wallace) was normalized to proportion average rank by dividing by the number of observations because the number of observations was not equal in all years.

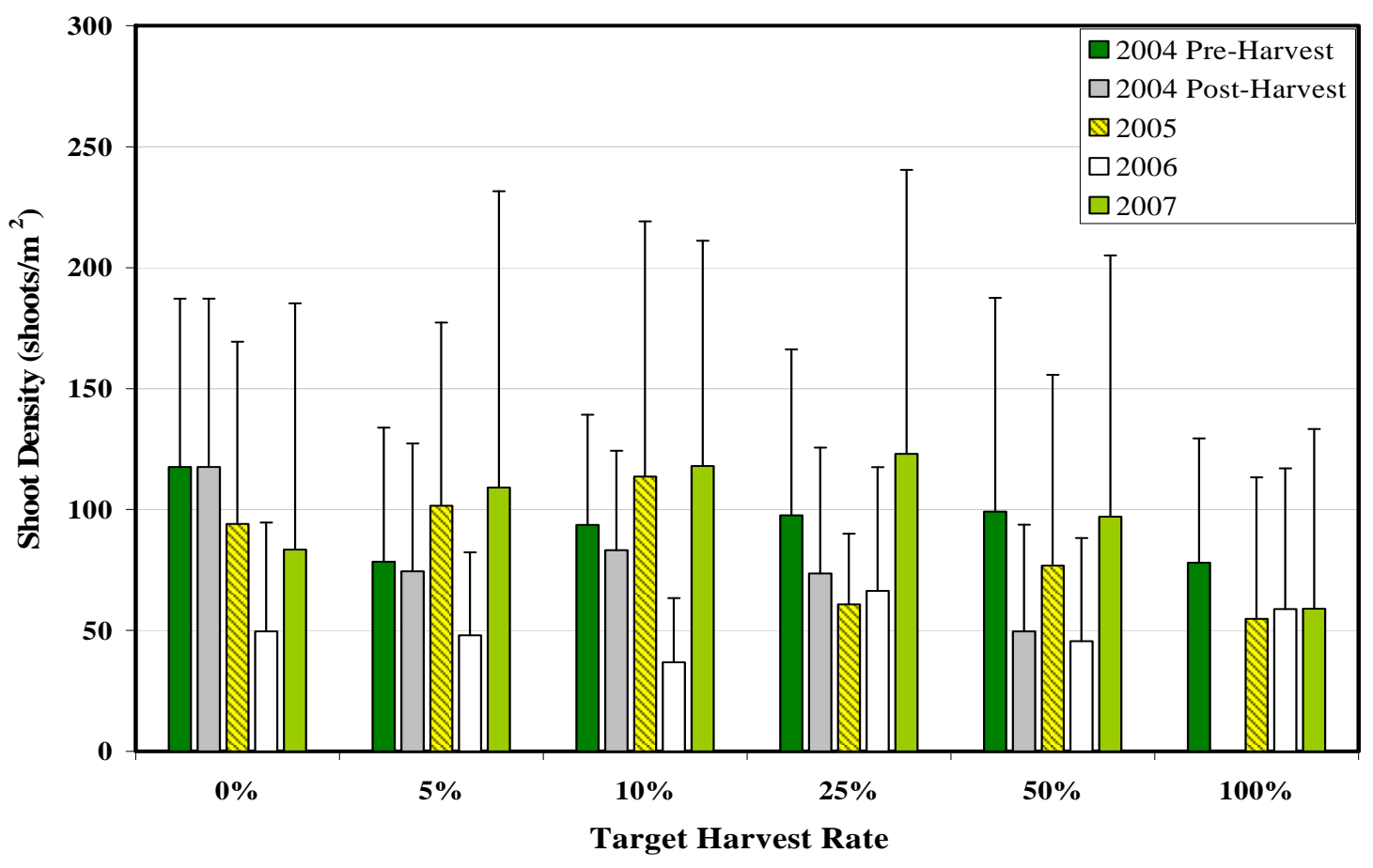

Figure 14. Mean Eelgrass Densities Before and After Harvest (bars indicate 1 standard deviation; $\mathrm{n}=10$ for $0 \%$ and $100 \%$ harvest rates; $\mathrm{n}=5$ for $5 \%, 10 \%, 25 \%$, and $50 \%$ harvest rates) 


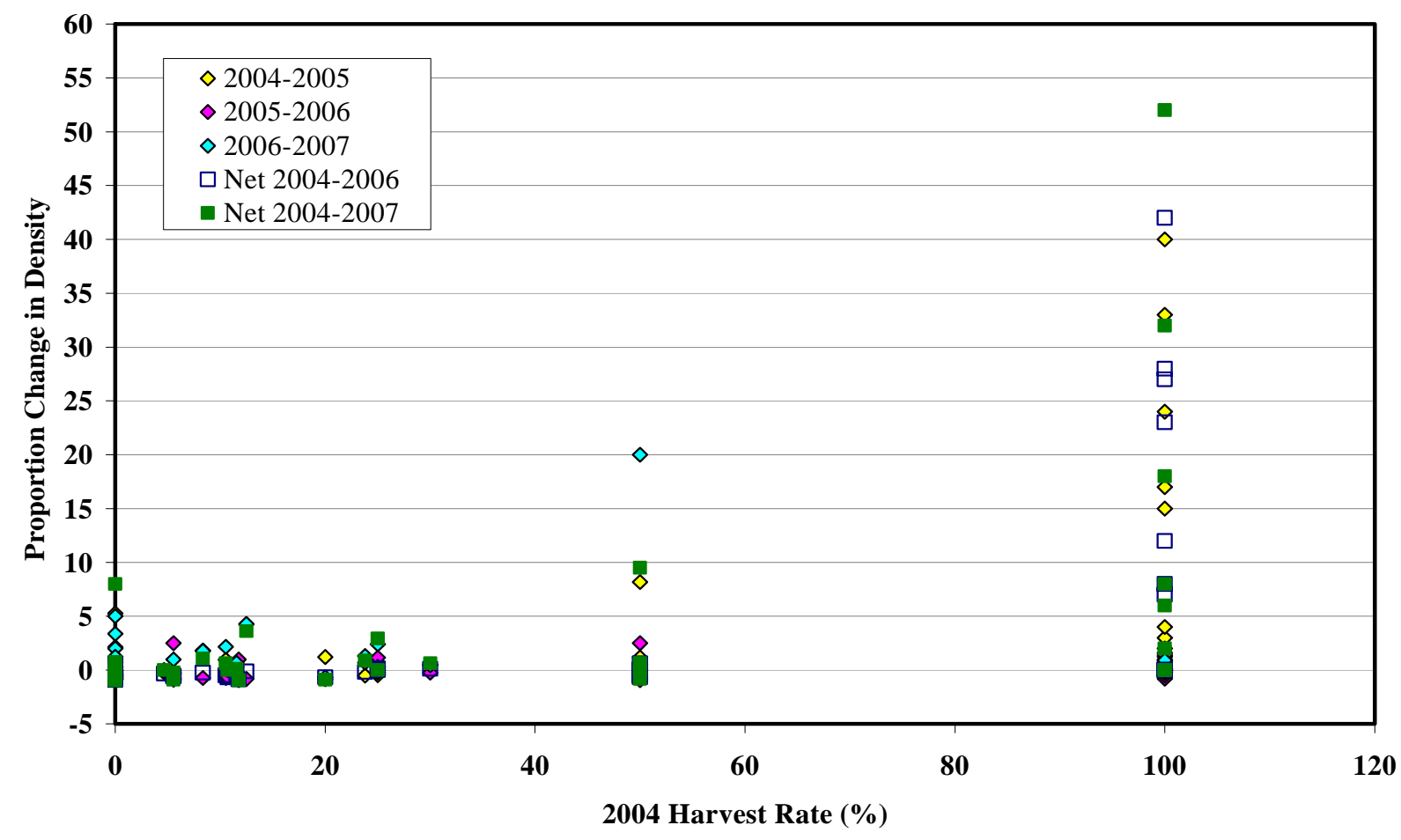

Figure 15. Interannual Proportion Change of Eelgrass Density as a Function of Harvest Rate

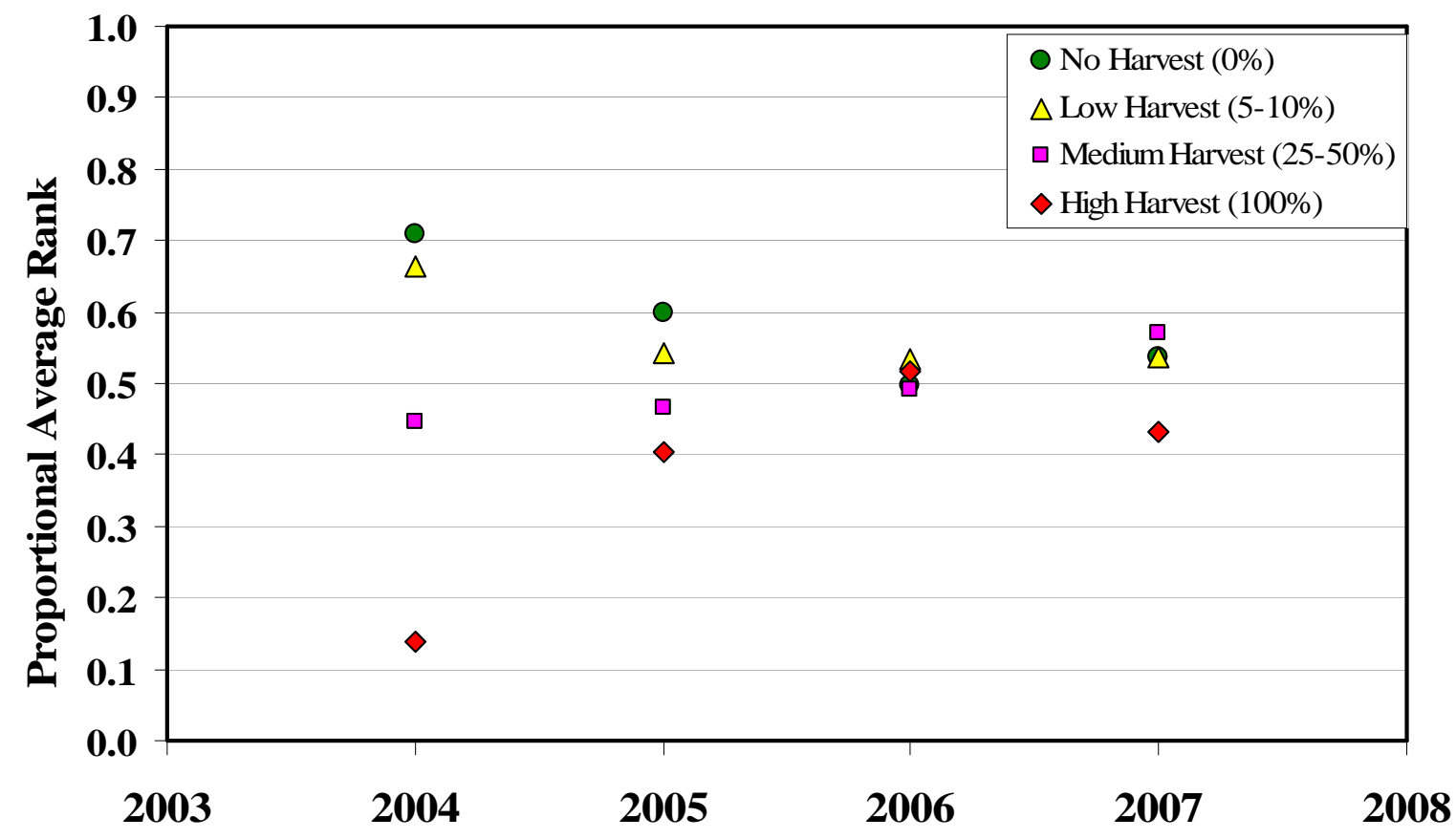

Figure 16. Proportional Average Rank of Shoot Density by Year 


\subsection{Eelgrass Experimental Harvest Plots: Conclusions and Future Activity}

The experimental harvest plots established in 2004 were monitored post-harvest in 2004 and in three subsequent years $(2005,2006$, and 2007). This year's data represent the final year of harvest plot monitoring. The implementation plan (King County 2006) outlined assessment of the experimental harvest plots post-harvest in 2005, 2006, and for the final time in 2008. However, it was agreed upon to move the final survey to 2007 in order to obtain three consecutive years of monitoring data. In addition, it was determined that three years' post-harvest (2007) shoot densities are not significantly different from pre-harvest densities at any percentage harvest rate (Kruskal-Wallace, $\mathrm{p}=0.73$ ); therefore, the harvest plots will not be monitored again. There was a net increase in eelgrass density from 2004 post-harvest to 2007 in all plots, despite density decreases observed in 2006 in all plots and at most harvest rates. Eelgrass densities within individual subplots were highly variable from year to year, and the change in density in any interannual period was not related to initial 2004 harvest rate. In addition, harvest rates of neighboring subplots did not appear to affect subplot eelgrass density (Woodruff et al. 2007).

The implications of these findings are encouraging in the sense that removal of eelgrass at several harvest levels did not significantly impact the re-growth and colonization of this site after harvesting, and recolonization through underground rhizome growth has occurred within several years in these modestsized eelgrass patches. However, it should be noted that these subplots are quite small $\left(0.25 \mathrm{~m}^{2}\right)$ compared with the size of the potential zone of impact to eelgrass (i.e., the Marine Outfall Corridor and close surrounding area). The plot sizes were necessarily limited simply because the available eelgrass patches located in the Marine Outfall Corridor in 2004 were quite small (Grette Associates 2005, Woodruff et al. 2006a). Within the coming year, several options will be considered for eelgrass mitigation, including removal of all of the eelgrass from the Marine Outfall Corridor prior to construction with subsequent stockpiling at the MSL, and then transplanting post-construction within the Corridor and surrounding areas as necessary. These plants would be supplemented by those currently held at the MSL. Finally, if plants are eventually needed from the donor site, the results of this study would indicate that plants removed from the donor site would be replaced relatively quickly through re-growth. If harvesting from the donor site does become necessary in the future, a harvest rate somewhat greater than $10 \%$ might be acceptable, however due to the small size of these experimental harvest plots, a more definitive harvest rate could not be determined from this study. 


\subsection{References}

Grette Associates, LLC. 2005. Eelgrass Program: 2004 Eelgrass Dive Survey Report. January 2005.

Prepared for King County, Department of Natural Resources and Parks, Wastewater Treatment Division, Seattle, Washington.

King County. 2004. Draft Eelgrass Restoration and Monitoring Plan. King County, Department of Natural Resources and Parks, Wastewater Treatment Division, Seattle, Washington.

King County. 2006. Eelgrass Restoration and Biological Resources Implementation Workplan (revised March 2006). Prepared by Grette Associates, Battelle Marine Sciences Laboratory, and King County Department of Natural Resources and Parks. Seattle, Washington.

Woodruff, DL, AB Borde, JA Southard, NP Kohn, NR Evans, and RM Thom. 2006a. First Annual Report: 2004 Pre-Construction Eelgrass Monitoring and Propagation for King County Outfall Mitigation. PNNL-15678-1. Prepared by Pacific Northwest National Laboratory, Marine Sciences Laboratory, Sequim, Washington, for King County Department of Natural Resources and Parks Wastewater Treatment Division, Seattle, Washington.

Woodruff, DL, NP Kohn, SL Southard, MG Anderson, VI Cullinan, J Vavrinec. 2007. Third Annual Report: 2006 Pre-Construction Eelgrass Monitoring and Propagation for King County Outfall Mitigation. PNNL-15678-3. Prepared by Pacific Northwest National Laboratory, Marine Sciences Laboratory, Sequim, Washington, for King County Department of Natural Resources and Parks Wastewater Treatment Division, Seattle, Washington.

Woodruff, DL, SL Southard, and JA Southard. 2006b. 2005 Pre-Construction Eelgrass Monitoring and Propagation for King County Outfall Mitigation. PNNL-15678-2. Prepared by Pacific Northwest National Laboratory, Marine Sciences Laboratory, Sequim, Washington, for King County Department of Natural Resources and Parks Wastewater Treatment Division, Seattle, Washington. 


\section{APPENDIX A}

\section{Experimental Harvest Plot Data}


Table A- 1. Eelgrass Monitoring Results in the Experimental Harvest Plots

\begin{tabular}{|c|c|c|c|c|c|c|c|c|c|}
\hline \multirow[b]{2}{*}{ Plot } & \multirow[b]{2}{*}{$\begin{array}{l}\text { Sub- } \\
\text { plot }\end{array}$} & \multirow{2}{*}{$\begin{array}{c}\text { Target } \\
2004 \\
\text { Harvest } \\
\text { Rate (\%) }\end{array}$} & \multirow[b]{2}{*}{$\begin{array}{l}2004 \text { Pre-harvest } \\
\text { Density } \\
\text { (shoots per } 0.25 \mathrm{~m}^{2} \text { ) }\end{array}$} & \multirow{2}{*}{$\begin{array}{l}\text { Number of } \\
\text { Shoots } \\
\text { Harvested } \\
\text { in } 2004\end{array}$} & \multirow[b]{2}{*}{$\begin{array}{c}\text { Actual } 2004 \\
\text { Harvest } \\
\text { Rate (\%) }\end{array}$} & \multicolumn{4}{|c|}{$\begin{array}{c}\text { Eelgrass Density } \\
\left(\text { shoots per } 0.25 \mathrm{~m}^{2}\right)\end{array}$} \\
\hline & & & & & & $\begin{array}{c}2004 \\
\text { Post- } \\
\text { harvest }\end{array}$ & 2005 & 2006 & 2007 \\
\hline Plot 1 & 11 & 5 & 12 & 1 & 8.3 & 11 & 33 & 8 & 24 \\
\hline Plot 1 & 12 & 10 & 8 & 1 & 12.5 & 7 & 41 & 6 & 36 \\
\hline Plot 1 & 13 & 0 & 28 & 0 & 0.0 & 28 & 10 & 6 & 21 \\
\hline Plot 1 & 14 & 0 & 26 & 0 & 0.0 & 26 & 23 & 7 & $34^{\mathrm{a}}$ \\
\hline Plot 1 & 15 & 50 & 14 & 7 & 50.0 & 7 & 8 & 12 & 11 \\
\hline Plot 1 & 16 & 25 & 16 & 4 & 25.0 & 12 & 6 & 14 & 50 \\
\hline Plot 1 & 17 & 100 & 24 & 24 & 100 & 0 & 40 & 7 & 8 \\
\hline Plot 1 & 18 & 100 & 22 & 22 & 100 & 0 & 24 & 23 & 18 \\
\hline Plot 2 & 21 & 25 & 10 & 3 & 30.0 & 7 & 11 & 8 & 12 \\
\hline Plot 2 & 22 & 0 & 14 & 0 & 0.0 & 14 & 19 & 8 & 0 \\
\hline Plot 2 & 23 & 10 & 26 & 3 & 11.5 & 23 & 11 & 15 & 26 \\
\hline Plot 2 & 24 & 50 & 28 & 14 & 50.0 & 14 & 15 & 15 & 24 \\
\hline Plot 2 & 25 & 0 & 12 & 0 & 0.0 & 12 & 1 & 0 & 2 \\
\hline Plot 2 & 26 & 5 & 18 & 1 & 5.6 & 17 & 12 & 8 & 1 \\
\hline Plot 2 & 27 & 100 & 9 & 9 & 100 & 0 & 3 & 8 & 6 \\
\hline Plot 2 & 28 & 100 & 18 & 18 & 100 & 0 & 1 & 0 & 2 \\
\hline Plot 3 & 31 & 100 & 32 & 32 & 100 & 0 & 15 & 28 & 32 \\
\hline Plot 3 & 32 & 10 & 38 & 4 & 10.5 & 34 & 67 & 17 & 56 \\
\hline Plot 3 & 33 & 50 & 10 & 5 & 50.0 & 5 & 54 & 2 & 62 \\
\hline Plot 3 & 34 & 0 & 54 & 0 & 0.0 & 54 & 37 & 21 & 37 \\
\hline Plot 3 & 35 & 100 & 8 & 8 & 100 & 0 & 33 & 27 & 52 \\
\hline Plot 3 & 36 & 5 & 7 & 0 & 0.0 & 7 & 49 & 11 & 71 \\
\hline Plot 3 & 37 & 25 & 42 & 10 & 23.8 & 32 & 15 & 26 & 61 \\
\hline Plot 3 & 38 & 0 & 40 & 0 & 0.0 & 40 & 38 & 31 & $71^{\mathrm{a}}$ \\
\hline Plot 4 & 41 & 100 & 48 & 48 & 100 & 0 & 4 & 12 & $\mathrm{ND}^{\mathrm{b}}$ \\
\hline Plot 4 & 42 & 0 & 50 & 0 & 0.0 & 50 & 32 & 11 & ND \\
\hline Plot 4 & 43 & 0 & 48 & 0 & 0.0 & 48 & 61 & 31 & ND \\
\hline Plot 4 & 44 & 5 & 43 & 2 & 4.7 & 41 & 32 & 27 & ND \\
\hline Plot 4 & 45 & 100 & 9 & 9 & 100 & 0 & 17 & 42 & ND \\
\hline Plot 4 & 46 & 25 & 44 & 11 & 25.0 & 33 & 25 & 33 & ND \\
\hline Plot 4 & 47 & 50 & 62 & 31 & 50.0 & 31 & 7 & 27 & ND \\
\hline Plot 4 & 48 & 10 & 28 & 3 & 10.7 & 25 & 23 & 7 & ND \\
\hline Plot 5 & 51 & 0 & 9 & 0 & 0.0 & 9 & 1 & 3 & 2 \\
\hline Plot 5 & 52 & 25 & 10 & 2 & 20.0 & 8 & 19 & 2 & 0 \\
\hline Plot 5 & 53 & 50 & 10 & 5 & 50.0 & 5 & 12 & 1 & 0 \\
\hline Plot 5 & 54 & 100 & 17 & 17 & 100 & 0 & 0 & 0 & 0 \\
\hline Plot 5 & 55 & 5 & 18 & 1 & 5.6 & 17 & 1 & 6 & 13 \\
\hline Plot 5 & 56 & 0 & 13 & 0 & 0.0 & 13 & 13 & 6 & 0 \\
\hline Plot 5 & 57 & 10 & 17 & 2 & 11.8 & 15 & 0 & 1 & 0 \\
\hline Plot 5 & 58 & 100 & 8 & 8 & 100 & 0 & 0 & 0 & 0 \\
\hline
\end{tabular}

a. One flowering shoot included in total number of shoots per $0.25 \mathrm{~m}^{2}$.

b. ND No data; Plot 4 was not surveyed in 2007 as the plot markers could not be located. 
Table A- 2. Eelgrass Monitoring Results at Each Harvest Rate

\begin{tabular}{|c|c|c|c|c|c|c|c|c|c|}
\hline \multirow[b]{2}{*}{ Plot } & \multirow[b]{2}{*}{$\begin{array}{l}\text { Sub- } \\
\text { plot }\end{array}$} & \multirow{2}{*}{$\begin{array}{c}\text { Target } \\
2004 \\
\text { Harvest } \\
\text { Rate (\%) }\end{array}$} & \multirow[b]{2}{*}{$\begin{array}{l}2004 \text { Pre-harvest } \\
\text { Density } \\
\text { (shoots per } 0.25 \mathrm{~m}^{2} \text { ) }\end{array}$} & \multirow{2}{*}{$\begin{array}{l}\text { Number of } \\
\text { Shoots } \\
\text { Harvested } \\
\text { in } 2004\end{array}$} & \multirow[b]{2}{*}{$\begin{array}{c}\text { Actual } 2004 \\
\text { Harvest } \\
\text { Rate (\%) }\end{array}$} & \multicolumn{4}{|c|}{$\begin{array}{l}\text { Eelgrass Density } \\
\text { (shoots per } 0.25 \mathrm{~m}^{2} \text { ) }\end{array}$} \\
\hline & & & & & & $\begin{array}{c}2004 \\
\text { Post- } \\
\text { harvest }\end{array}$ & 2005 & 2006 & 2007 \\
\hline Plot 1 & 13 & 0 & 28 & 0 & 0.0 & 28 & 10 & 6 & 21 \\
\hline Plot 1 & 14 & 0 & 26 & 0 & 0.0 & 26 & 23 & 7 & $34^{\mathrm{a}}$ \\
\hline Plot 2 & 22 & 0 & 14 & 0 & 0.0 & 14 & 19 & 8 & 0 \\
\hline Plot 2 & 25 & 0 & 12 & 0 & 0.0 & 12 & 1 & 0 & 2 \\
\hline Plot 3 & 34 & 0 & 54 & 0 & 0.0 & 54 & 37 & 21 & 37 \\
\hline Plot 3 & 38 & 0 & 40 & 0 & 0.0 & 40 & 38 & 31 & $71^{\mathrm{a}}$ \\
\hline Plot 4 & 42 & 0 & 50 & 0 & 0.0 & 50 & 32 & 11 & ND \\
\hline Plot 4 & 43 & 0 & 48 & 0 & 0.0 & 48 & 61 & 31 & ND \\
\hline Plot 5 & 51 & 0 & 9 & 0 & 0.0 & 9 & 1 & 3 & 2 \\
\hline Plot 5 & 56 & 0 & 13 & 0 & 0.0 & 13 & 13 & 6 & 0 \\
\hline Plot 1 & 11 & 5 & 12 & 1 & 8.3 & 11 & 33 & 8 & 24 \\
\hline Plot 2 & 26 & 5 & 18 & 1 & 5.6 & 17 & 12 & 8 & 1 \\
\hline Plot 3 & 36 & 5 & 7 & 0 & 0.0 & 7 & 49 & 11 & 71 \\
\hline Plot 4 & 44 & 5 & 43 & 2 & 4.7 & 41 & 32 & 27 & ND \\
\hline Plot 5 & 55 & 5 & 18 & 1 & 5.6 & 17 & 1 & 6 & 13 \\
\hline Plot 1 & 12 & 10 & 8 & 1 & 12.5 & 7 & 41 & 6 & 36 \\
\hline Plot 2 & 23 & 10 & 26 & 3 & 11.5 & 23 & 11 & 15 & 26 \\
\hline Plot 3 & 32 & 10 & 38 & 4 & 10.5 & 34 & 67 & 17 & 56 \\
\hline Plot 4 & 48 & 10 & 28 & 3 & 10.7 & 25 & 23 & 7 & ND \\
\hline Plot 5 & 57 & 10 & 17 & 2 & 11.8 & 15 & 0 & 1 & 0 \\
\hline Plot 1 & 16 & 25 & 16 & 4 & 25.0 & 12 & 6 & 14 & 50 \\
\hline Plot 2 & 21 & 25 & 10 & 3 & 30.0 & 7 & 11 & 8 & 12 \\
\hline Plot 3 & 37 & 25 & 42 & 10 & 23.8 & 32 & 15 & 26 & 61 \\
\hline Plot 4 & 46 & 25 & 44 & 11 & 25.0 & 33 & 25 & 33 & ND \\
\hline Plot 5 & 52 & 25 & 10 & 2 & 20.0 & 8 & 19 & 2 & 0 \\
\hline Plot 1 & 15 & 50 & 14 & 7 & 50.0 & 7 & 8 & 12 & 11 \\
\hline Plot 2 & 24 & 50 & 28 & 14 & 50.0 & 14 & 15 & 15 & 24 \\
\hline Plot 3 & 33 & 50 & 10 & 5 & 50.0 & 5 & 54 & 2 & 62 \\
\hline Plot 4 & 47 & 50 & 62 & 31 & 50.0 & 31 & 7 & 27 & ND \\
\hline Plot 5 & 53 & 50 & 10 & 5 & 50.0 & 5 & 12 & 1 & 0 \\
\hline Plot 1 & 17 & 100 & 24 & 24 & 100 & 0 & 40 & 7 & 8 \\
\hline Plot 1 & 18 & 100 & 22 & 22 & 100 & 0 & 24 & 23 & 18 \\
\hline Plot 2 & 27 & 100 & 9 & 9 & 100 & 0 & 3 & 8 & 6 \\
\hline Plot 2 & 28 & 100 & 18 & 18 & 100 & 0 & 1 & 0 & 2 \\
\hline Plot 3 & 31 & 100 & 32 & 32 & 100 & 0 & 15 & 28 & 32 \\
\hline Plot 3 & 35 & 100 & 8 & 8 & 100 & 0 & 33 & 27 & 52 \\
\hline Plot 4 & 41 & 100 & 48 & 48 & 100 & 0 & 4 & 12 & $\mathrm{ND}^{\mathrm{b}}$ \\
\hline Plot 4 & 45 & 100 & 9 & 9 & 100 & 0 & 17 & 42 & ND \\
\hline Plot 5 & 54 & 100 & 17 & 17 & 100 & 0 & 0 & 0 & 0 \\
\hline Plot 5 & 58 & 100 & 8 & 8 & 100 & 0 & 0 & 0 & 0 \\
\hline
\end{tabular}

a. One flowering shoot included in total number of shoots per $0.25 \mathrm{~m}^{2}$.

b. ND No data; Plot 4 was not surveyed in 2007 as the plot markers could not be located. 
PNNL-15678-4

\section{Distribution}

No. of

Copies

\section{OFFSITE}

6 Kim Stark

King County Department of Natural

Resources and Parks

Wastewater Treatment Division,

Brightwater Project

201 South Jackson Street, Suite 503

Seattle, WA 98104-3855
No. of

Copies

\section{ONSITE}

6 Pacific Northwest National Laboratory

D.L. Woodruff

SEQUIM

N.P. Kohn

SEQUIM

S.S. Southard

SEQUIM

V.I. Cullinan

SEQUIM

J. Vavrinec

SEQUIM

Information Release

K1-06 